\title{
Contradictions and Tensions in Students' Motives of Enrolling in a Teacher Education Programme in Zimbabwe
}

\author{
Young Mudavanhu \\ Correspondence: Young Mudavanhu, Bindura University of Science Education, UK
}

Received: November 27, 2014

Accepted: December 11, 2014 Online Published: February 25, 2015

doi:10.11114/jets.v3i2.596

URL: http://dx.doi.org/10.11114/jets.v3i2.596

\begin{abstract}
This study explored identities commonly used in teacher education and student teachers' motives for becoming a teacher. The qualitative case methodology employed interviews and biographical questionnaires data collection methods. Data was gathered through interviewing student teachers and lecturers. Qualitative data analysis began by defining a priori themes and identifying parts of the interview transcripts that were relevant to these a priori themes. The initial coding was then refined by adding additional codes which emerged from the data to create a final coding template to interpret findings. Data analysis methods revealed that student teachers were motivated to join teaching by chance, important other, remuneration, vocation and interest developed through work experience. However prospective candidates did not get places to train as teachers on the basis of their motivation to become teachers. Further the study revealed that motives influenced "what", "where", and "how" student teachers were learning. This study recommends using interviews to establish motives as a way to supplement selection of student teachers.
\end{abstract}

\section{Introduction}

Studying student teachers' motives is important for a number of reasons. Recruiting and retaining qualified teachers who are motivated and committed to teach is important in ensuring quality education (Richardson \& Watt, 2005). Knowing motives is critical in attracting potential candidates to join teaching and reducing shortage of teachers especially in mathematics and science. Further, understanding motives can help to reduce high staff turnover and teachers leaving profession early in their careers. Research has shown that enthusiasm and commitment to teaching (Rikard, 1999) were important factors in determining quality of teaching. Teachers who were motivated and loved teaching were likely to get students motivated towards learning (Czubaj, 1996). The need to examine prospective teachers' motives (be they motivations, aspirations, or early career development) in the climate of escalating teacher shortage has increasingly been the focus of research internationally (Richardson \& Watt, 2005). Teacher recruitment and retention has been an issue in UK in the 1990s and early $21^{\text {st }}$ century. Studies to establish factors that either attracted or alienated potential recruits (or those already in training) have been conducted in UK, for example; Reid \& Caudwell (1997), Kyriacou \& Coulthard (2000), Whitehead \& Postlethwaite (2000), Andrews \& Hatch (2002), and Younger, Brindley, Pedder \& Hagger (2004). Similarly studies were carried out in America (Cochran-Smith \& Zeichner, 2005; Bastick, 2000), Europe (Fokkens-Bruinsma \& Canrinus, 2011; Bruinsma \& Canrinus, 2012), Asia (Yong, 1995; Chan, 2004) and Africa (Chivore, 1988). Understanding motives can be used to help student teachers to narrow the gap between personal biographies and expectations in teacher education.

Socio-cultural and socio-economic contexts may have an impact on prospective teachers' motivation for teaching (Thomson, Turner \& Nietfeld, 2012). In Europe and Australia research suggests most prospective teachers reported altruistic reasons and enjoyment in working with children (Kyriacou \& Coulthard, 2000; Richardson \& Watt, 2005; Fokkens-Bruinsma \& Canrinus, 2011). In Australia the Department of Education, Science and Training found out that salaries, employment conditions and the social status of teachers make teaching a less than attractive career for the most gifted university graduates (Richardson \& Watt, 2005). In developing nations like Brunei (Yong, 1995), Jamaica (Bastick, 2000) and Zimbabwe (Chivore, 1988) research revealed that extrinsic motivations were important for choosing (or not choosing) a teaching career. Unattractive working conditions have been reported in Africa, for example, perceived low salary, unattractive work locations, and unprofessional treatment of teachers (Mulkeen et al., 2007). Low salaries and poor working conditions have been reported as the main reasons for pushing out potential teacher candidates in Zimbabwe (Chireshe \& Shumba, 2011; Marist International Solidarity Foundation, 2011). It 
appears student teachers' motives for becoming teachers are determined to some extent by contextual factors.

Student teachers' biographies seem to be critical in understanding their motives, identities and learning to teach experiences. Researches in teacher education reveal discrepancies between "actual" identity (history) and "designated" identity (Sfard \& Prusak, 2005). Actual identity describes who student teachers are, that is, their personal histories whereas designated identity means who they (or teacher educators) want them to be (Postlethwaite \& Haggarty, 2010). If the gap between student teachers' actual identity and designated identity is not closed they were "in danger of becoming the kind of teacher that fits the school system's notion of a good teacher" (Postlethwaite \& Haggarty, 2010, p. 5).

Student teachers' personal histories tend to have a filtering effect of what they learn in teacher education courses (Trotman \& Kerr, 2001). In literature it has been reported that student teachers reject aspects that do not "resonate with the observational apprenticeship" (Trotman \& Kerr, 2001, p. 159). Student teachers' professional development and abilities to question taken-for-granted assumptions about teaching and learning into, for example, reflective practitioners are restricted by progressive filtering (Trotman \& Kerr, 2001). Further, progressive filtering appears to be a consequence of socialisation of beginning teachers. Student teachers encountering contradictions between university-value system and the school-value system find it reasonable to align with the school system they are joining and with colleagues who hold power in the new settings (Postlethwaite \& Haggarty, 2010).

Younger et al. (2004) found contradictions and tensions between the beginning teachers' "sophisticated grasp of the kind of teachers they wanted to become" and "the relatively unsophisticated analysis of the essential characteristics of this practice of the process of learning which they needed to undergo if they were to fulfil these ambitions" (Younger et al., 2004, p. 262) and suggest that teacher educators should provide "the contexts and the methodologies" whereby beginning teachers can reflect upon their own preconceptions and refine their own understanding of teaching and learning.

Motives, power and personal starting points are influenced by society and create a system of expectations, therefore, socio-cultural theory is useful in understanding the nature and practice of learning to teach. Actors in teacher education, for example lecturers, and students learning to become teachers, interact within a system of expectations. The expectations include what these actors bring and what others have about the learning activities and practices. Lecturers engage with their tasks on the basis of their understanding of what it means to be a lecturer. Students learning to become teachers join the teacher education programme with ideas about how as students they ought to behave. Outsiders, who have an interest in teacher education, have ideas about training of teachers and expectations that influence, shape and limit what insiders do. Different points of the system have different motives. It is therefore necessary to look at socio-cultural theory.

Socio-cultural theory suggests that individuals' understandings and practices are always shaped by the various settings in which they find themselves (Grossman et al., 2000). Besides focusing on social settings, using socio-cultural theory implies accepting that individuals' participation in an activity often means trying to achieve two or more conflicting goals at the same time, and the latter had a bearing on how the available resources are used. In this study the aim was to understand, through students' and lecturers' perceptions, why students joined teacher training and how motives impacted on learning to teach.

\section{Research Questions}

Three research questions were used to guide the study.

1. How do student teachers and lecturers describe their identities?

2. What are student teachers' motives of enrolling in a teacher education programme?

3. How do student teachers' identities and motives shape learning to teach?

\section{Methodology}

In my qualitative study participants were interviewed to enable an in-depth understanding and interpretation of students' and lecturers' perceptions of learning to teach. Students and lecturers were prompted to talk about their background using the open questions 'tell me about yourself', 'what did you bring to teacher education?' 'why did you (your student) decide to become a teacher?' Participants were asked to fill in a short biography questionnaire on which they described their gender, age, qualifications, specialism, work experience and preferred mode of interview.

Qualitative methods were used to analyse data in the form of documents and completed interview transcripts (Bogdan \& Biklen, 1992). Data analysis meant a search for meaning (Stake, 1995), and involved direct interpretation of the instance. Data analysis began by defining a priori themes and identifying parts of the interview transcripts that were relevant to these a priori themes. The initial coding was then refined by adding additional codes which emerged from 
the data to create a final coding template to interpret findings. The main data analysis stage involved coding at various levels beginning with manual open coding in MS word and EXCEL worksheets. At the second level of coding, similar open codes were collapsed into higher order headings called broader categories. At the third level of analysis expansion was achieved by writing storylines and later included participants' voices as evidence. Teacher motives emerged from analysis of participants' responses to open ended interviews.

The participants in the study reported here were Bachelor of Science Education Honours students and lecturers at University of Mashonaland (pseudonym) during the period 2008-2011 when the study was conducted. The target populations were 57 pre-service students, 44 in-service students and 15 lecturers in Department of Education. From these six pre-service students, five in-service students and 14 lecturers were interviewed. Students who were at the university when field work was conducted were approached, and their voluntary participation was sought. Sampling was therefore convenient. The major weakness of the convenience sample is that there is no control over representativeness of the population such that findings cannot be used to generalize to a wider population. Universities in Zimbabwe offer mainly two routes into teaching: either a first degree (3 years duration) in a teaching subject within the school curriculum followed by a Post-Graduate Certificate/Diploma in Education (1-2 years duration) or Bachelor of Education degree (2-3 years duration) for candidates who hold a diploma/certificate in education from a teachers' college, and who have experience of teaching. University of Mashonaland was unique in training teachers through a combination of studying academic subjects and professional courses simultaneously leading to a Bachelor of Science Education degree ( 3 or 4 years duration).

\section{Findings}

The findings reported here are from a larger study that was aimed at understanding students' and lecturers' perceptions of learning to teach. In this part of the study the focus was on understanding background and motives of student teachers.

\subsection{Participants'Biographies-Gender, Age and Work Experience}

In the study 25 participants were interviewed. As shown in Table 1 more males than females participated in the study and these were distributed as follows; six pre-service students, of whom one was female; five in-service students, of whom two were female; and 14 lecturers, six being female. While gender inequalities apparent in my study could be representative of education systems in Africa (Muhwezi, 2003), this needs to be treated with caution because the purpose of the case study reported and convenient sampling technique used were not aimed at making generalisations.

Table 1 . The age and gender distribution of participants $n=25$

\begin{tabular}{llll}
\hline Age (years) & $\begin{array}{l}\text { Female } \\
\text { Gender } \\
\text { (frequency) }\end{array}$ & $\begin{array}{l}\text { Male } \\
\text { Gender } \\
\text { (frequency) }\end{array}$ & Percentage \% \\
\hline $21-30$ & 1 & 6 & 28 \\
$31-40$ & 5 & 3 & 32 \\
$41-50$ & 2 & 6 & 32 \\
$51+$ & 1 & 1 & 08 \\
Percentage \% & 36 & 64 &
\end{tabular}

The students interviewed were either school leavers (pre-service) or students who join university with some teaching qualification and teaching experience (in-service). Pre-service students were generally younger than in-service students. Most students were in the age group 21-30 years. The majority of lecturers were aged 41-50 years.

Participants' work experiences, shown in Table 2, indicate 48\% had less than five years and 52\% had six years or more teaching experience.

Table 2. Work experience of participants $n=25$

\begin{tabular}{|c|c|c|c|}
\hline $\begin{array}{l}\text { Work experience } \\
\text { (years) }\end{array}$ & $\begin{array}{l}\text { Female } \\
\text { Gender } \\
\text { (frequency) }\end{array}$ & $\begin{array}{l}\text { Male Gender } \\
\text { (frequency) }\end{array}$ & $\begin{array}{l}\text { Percentage } \\
\%\end{array}$ \\
\hline 0 & 1 & 5 & 24 \\
\hline $1-5$ & 3 & 3 & 24 \\
\hline $6-10$ & 1 & 1 & 08 \\
\hline $11+$ & 4 & 7 & 44 \\
\hline Percentage $\%$ & 36 & 64 & \\
\hline
\end{tabular}


In-service students had a minimum work experience of two years, as this was one of the requirements to enrolling at UoM. Pre-service students came straight from high school and needed two A-Level passes. Lecturers had diverse work experience. Most, if not all, had been classroom teachers, others had been trainers at diploma level in teachers' college and some had been education administrators.

In my study males were twice as many as females among the participants. Most participants were aged 40 years or less. Participants were equally divided between those with no work experience and those with 6 years or more teaching experience. In England providers of training make it clear that work experience can help ensure a career in teaching is right for an individual and increases one's chances of getting on a teacher training course (Carmody, 2011; TDA, 2012); something not evident in my findings of the Zimbabwe context.

\subsection{How Participants Described Their Identities}

Altogether participants talked much about students and teachers, as if to suggest that these were the key stakeholders in teacher education. From interviews with lecturers commonly mentioned stakeholder was student, then lecturer and teacher in that order. Students identified actors in teacher education in order of their areas of 'specialism', 'teacher' and 'student'. Most lecturers were conscious of their position(ing) (Trent, 2011) from the beginning of the conversations. For example, L3 describes himself as lecturer teaching citizenship education.

I am a lecturer in the Department of Education, which is under the Faculty of Science Education. I teach Citizenship Education and also ... since I am in the Department of Education I also help teachers... teacher training... for teaching practice and things like that. (Interview with L3)

Lecturer L7 described herself as someone with suitable qualifications to train science teachers. She talked about others lacking the 'right' qualifications. Such a perceived identity seem to suggest giving oneself a more privileged position (Trent, 2011) than the rest of the lecturers or 'us and them' division (Maclure, 2003; Trent, 20011). A commonly used identity of lecturer like L7 was science educator, emphasizing specialism in science.

I would say ... let us say here we have the concept of Physics Educator, Chemistry Educator and Mathematics Educator. Now (if) even the foundation courses like Sociology, Psychology and Philosophy. But we are training science teachers. So in my view if you are a BA holder you have a teacher qualification in arts like English and Shona. Now you have a foundation course ... qualification, I think you are better placed in an institution which trains teachers in Humanities not an institution which trains science teachers. Yes you have all the theories ... sociology theories and psychology theories but how relevant are the theories to the science teacher? (Interview with L7)

Student teachers assumed various identities. Some described their specialism, for example, Chemistry teacher. Others talked about stage of their training that they had completed training and were waiting for their results. Student S1 is clear about her specialism and stage of training.

I am S1, a BScEd Hon degree student majoring in Chemistry. My minor subject is Biology... I have just finished my degree. I sat for my last examination on Friday. (Interview with S1)

At university lecturers saw students as adult learners, and identified them as student teachers. The lecturers divided students into various groups such as pre-service students if they were coming straight from high school, in-service students if they had some teaching qualification and work experience, and undergraduate (and postgraduate). Lecturers e.g. L15 cited above believed that students assumed various identities depending on the context (Trent, 2011). In one instant they would be identified as students and in another as teachers during applied science education (ASE). At UoM teaching practice is termed applied science education.

They are identified at unit level. Here they are just students. They are learners and adult learners. Universities in Zimbabwe use the word adult because our law says anyone who is above 18 is an adult... They are student teachers. The parents do not differentiate. The secondary students, yes they are quick to pick. But the way they are treated by school heads they take exactly what I call the responsibility of the classroom like any other teachers. So their students understand that the student teachers are as good as any other teachers (Interview with L15).

Lecturers could be divided into two groups; science educators, who had studied science education to get Bachelor of Education and Master of Science Education degrees, and theorists who had studied philosophy in education, psychology in education, and sociology in education at postgraduate level. A third group of lecturers, taught support courses, for example, communication skills, citizenship education and health education. These had specialised in languages and humanities before doing a postgraduate study in education. Science educators were teaching pedagogics and saw themselves as specialists in content. They also believed that as science educators they were competent to teach both 
theory and content because they had both subject content and pedagogy. Theorists (non-science educators) were described as specialists in educational theory.

In short participants were identified using their positions at university or school; student and lecturer. In schools students were 'teachers'. Participants also identified themselves using their subject of specialism, with $20 \%$ reporting a non-science teaching subject.

\subsection{Participants' Views about Student Teachers' Motives}

Participants talked mainly about five possible reasons why students chose teaching namely; no choice, important other, remuneration, vocation and work experience.

\subsubsection{No Choice}

Participants talked about being forced to become teachers because of circumstances, and lack of choices. For example, L8 decided to become a teacher because of lack of choices.

Aaaa-ah! I found myself being a teacher in fact. It was during that time of the colonial era, where there was actually no choice. As an African one had to be either a nurse or a teacher. Those were the only options left for us. (Interview with L8)

Lecturer L14 seem to suggest that when one got low points at A-level career choices were limited and ended taking up teaching. Enrolling in a teaching degree was out of desperation because the preferred non-teaching degrees were either not available or required one to have good A-Level passes.

Eee-e. It was by coincidence. At first I did not want to become a teacher. But I applied for ... for my background as a physicist scientist ... I have done science at A-Level. I wanted to get into engineering, medicine, and other technical areas but did not get the opportunities. When this opportunity of becoming a teacher came my way I grabbed it... it is out of desperation, it is out of opportunities. (Interview with L14)

Student teachers talked about not wanting to be teachers. For example, S3 had this to say

Teaching degree! Ummmm! It was not a matter of choice... in fact I was planning to become a medical doctor... (Interview with S3)

Similarly, S1 had no intention of becoming a teacher

Actually, initially I did not know that I was going to become a teacher... I just applied for a degree programme, got a place and then realised that it was a teaching degree. Then I said to myself, I might as well continue. (Interview with S1)

In general teaching was not a first choice for most lecturers and student teachers.

\subsubsection{Important Other}

Another reason for choosing teaching was to please 'important other'. For example L7 joined teaching because of influence from her father.

...I happened to be born out of teachers. So it was my first post of call. Though I could have taken up a different profession, it was because of health problems. It was my father who said that ... who asked me to divert to teaching ... to a college which was closer to him so that he could monitor my health instead of going to BGH where I had got an A-level place. (Interview with L7)

L6 was inspired to like teaching by her geography teacher.

(laughing). It is unbelievable. There was a teacher who taught me from Form I to Form VI, when I was at Goromonzi High. He was dedicated to his work. I remember he was promoted twice once when we were in Form IV and the other time when we were in Form V, and he chose to remain a classroom teacher and to see us complete our O-Levels and A-Levels. Each time he would say let me see this group through... Then I said I want to be a geography teacher. (Interview with L6)

S2 was inspired to join teaching by his grade teacher

One teacher combined classes and took us into grade 7. He was able to motivate us and at the end we dominated the top 15 in grade seven examinations. He inspired me and motivated me to want to become a teacher. (Interview with S2)

Some lecturers had joined teaching because of 'important other'. Family influence came from spouses, brothers and sisters, and parents. Similarly student teachers had been influenced by family members to join teaching, schooling experience and important teacher in their lives. My discoveries were consistent with influence from others (Chan, 2004), a sense of inevitability (Andrews \& Hatch, 2002), inspiration from role models (Low, Lim, Ch'ng and Goh, 2011, 2011) 
and adaptive motives (Bruinsma \& Jansen, 2010).

\subsubsection{Remuneration (Extrinsic Motivation)}

Participants talked about students' reasons for joining teaching that could be described as extrinsic, and such reasons ranged from route to employment, job security to life-long learning. L2 describes teaching as a profession offering job security and thinks this explains why her students chose the teaching career.

Well... the job... It offers job security... You are aware that some companies do very well and pay very well but eventually they fold up. But teaching is one job which will always be there. Children are born and so there will always be someone coming to school. As long as you are always able to teach, teaching offers a job security. (Interview with L2)

According to S8, teaching was unpopular, because people did not like the low pay, and most students were forced to become teachers by the prevailing circumstances.

In Zimbabwe many people do not want remuneration paid teachers and therefore do not want to train as teachers. Those who come here mostly.... the students' attitudes... most students who come here do not want to become teachers. I would say they are forced to join the profession by various situations. (Interview with S8)

The economic problems facing the country at the time of the study were discouraging would be teachers, and because of low remuneration received by teachers the profession was looked down upon. Despite the low pay teaching was better than nothing; described in literature as a stepping stone (Low et al., 2011), job conditions (Chan, 2004), teaching as a fallback (Fokkens-Bruinsma \& Canrinus, 2011) and a sense of inevitability (Andrews \& Hatch, 2002). It seems clear that another motive for joining teaching was high chances of employment and remuneration consistent with extrinsic motivation (Chan, 2004; Hobson \& Malderez, 2005, Bruinsma \& Jansen, 2010).

\subsubsection{Vocation-Teaching as a Calling}

L1 and L4 joined teaching because of passion and for the love of teaching. Still others had an interest in science teaching. The reasons given here seem to suggest seeing teaching as a calling, something that could be described as altruistic and intrinsic motivation.

One it was because of the passion of the profession... For example I was just interested in science and I managed to get a place to train as a science teacher. (Interview with L1)

I (pause) became a teacher for a number of reasons. One of them is that I love to see people learning and I think teaching places one in a better place to help people learning. Because I think learning is life or part of life and so I get involved not only in my life but in other people's lives. I think I can make a difference. (Interview with L4)

First of all besides attaining it as a tangible reward, I am actually interested in the way teachers emphasize points... responsible feeling... in front of kids trying to... actually I like interacting with pupils (Interview with S2)

Some students' motives for joining teaching were vocation, to contribute to society by helping people learn, and for the love of children. Similar descriptions of motives are found in literature e.g. altruistic and intrinsic motivation (Chan, 2004; Hobson \& Malderez, 2005), a desire to work with people (Andrews \& Hatch, 2002) and to answer a higher calling (Low et al., 2011).

\section{3. 5 Work Experience}

Participants talked about students joining teaching because of their prior knowledge, training and work experience. Student teachers, with some training, talked about their prior teaching experience, interpreted to mean that they were influenced to study B.ScEd. because of work experience. Some lecturers, for example L8, had been motivated by working as unqualified teachers to realise that the teaching job was, after all, interesting. Similarly, Andrews \& Hatch (2002) found out that people became teachers because of their experiences as learners, and Bruinsma \& Canrinus (2012) refer to perceptions of the task. Not only is work experience a motivator, in some countries like England it is a requirement (Carmody, 2011; TDA, 2012). Figure 1 shows distribution of participants' views about student teachers' motives. 


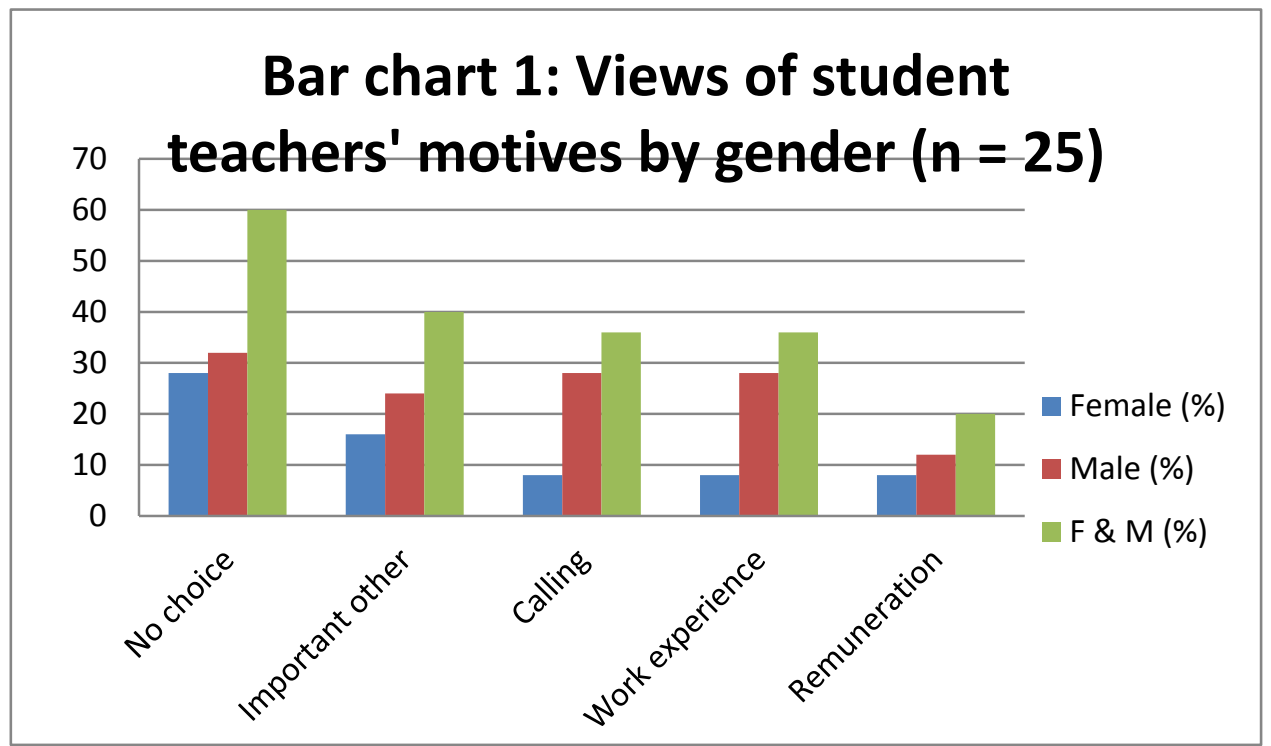

Figure 1. Distribution of participants' views about student teachers' motives

\section{How Participants' Identities and Motives Shaped Learning to Teach}

\subsection{How Participants' Perceptions of Their Own Identities Shaped 'What' and 'Where'Student Teachers Were Learning}

Participants were asked to talk about learning to teach and prompted through such questions as what do you (student teachers) learn? Where do you (they) learn? How do you (they) learn? The study found out that participants' perceptions of their own identities shaped 'what' and 'where' student teachers were learning. Student teachers believed that they were learning subject matter knowledge and lecturers talked about the education courses they were teaching.

Lecturer L7 mentioned all sort of various things when asked to talk about what students took out of her course, ranging from knowledge, skills, theory and practice.

Knowledge... teaching knowledge and skills after teaching them. Knowledge and skills ... because when they are here ... though we are concentrating on theory... but because of the experience I have talked about, my teaching is slightly different and whatever I do is quickly translated into practice in the same lecture. So I feel when they go out they are equipped with knowledge to use and why to teach and they also have skills to handle dynamic and unique situations because no none classroom is the same. (Interview with L7)

Participants used the expressions theory, concepts, courses, ideas, information, knowledge and topics to describe what student teachers were learning as educational theory. The code 'pedagogy' was used for participants' descriptions of educational technology, pedagogics, classroom management, lesson planning and strategies of how to teach. When participants mentioned subject areas, mathematics, chemistry and computer science the label 'subject matter' was used. The study used the label 'support' for communication skills, citizenship education and health education. Data shows that most lecturer-participants' comments were about learning educational theory. However, student-teacher-participants talked much more about learning subject matter knowledge than lecturers.

The study found out that participants' perceptions of their own identities shaped 'where' student teachers were learning. The study coded descriptions of university or lecture room as 'university setting' and classroom, teaching practice and school as the 'school setting'. For descriptions of other settings, for example, "everywhere” the label 'other setting' was used. The pattern seems to suggest that students where learning mostly at university in the lecture-room.

Lecturer L4 believed that students learn in the lecture room, library, where they resided and social settings, for example, informal groups.

Traditionally students I think they learn in the lecture, in the library, and when they are reading. I would also think those are the major areas but we encourage students to learn cooperatively in informal groups, that they form. I also think they learn as they are in places of residence as they discuss in small groups. (Interview with L4)

Lecturer L6 believed that students learnt most in school during teaching practice.

The classroom, day-to-day living, interaction with teachers... I would say in schools when they do ASE... You know when you are at university ... you memorize. When they go out during ASE they are trying to put into practice what they have learnt at university and see that this does not work, and this work. (Interview with L6) 
S8 talked about learning to teach everywhere, for example, where students live, outside lecture rooms, during spare time, during vacation, and during school attachment and during classroom teaching. Out of all these settings and contexts S8 believed that student teachers learnt most in the lecture room at university.

Most of the learning takes place here at university. But I also learn when I go into schools and teach to apply courses learnt at university like advanced pedagogics... Basically I like learning in the lecture room where the lecturer is there disseminating information. (Interview with S8)

Student S3 seem to suggest that what happens in the lecture room ultimately determines what he was going to learn in other places like library.

I learn in the lecture room, and in the library and the computer laboratory...But in the lecture room I think that is where I get most of the knowledge and most of the curiosity to go and search further... In the lecture that is where what happens there prompts me to go and search further. It directs me what to learn. It gives me the zeal, the force, the push to want to learn... It pushes me and then I go to the library to search for information, and later discuss with my colleagues in small groups as a team. The lecture is essential to trigger me to want to learn. It is essential (laughing) and so is the library. They are inter-dependent. (Interview with S3)

Participants' comments suggesting that student teachers learnt most in the lecture-room were consistent with perceived identities of student teacher and lecturer. The lecturer was identified as the source of knowledge, and student teachers believed that knowledge received from lecturers was needed to attain good grades in examinations.

\subsection{How Student Teachers' Motives Shaped 'How' They Were Learning}

Student teachers and lecturers commented that various teaching methods were employed. The single dominant approach was the lecture as evidenced by $25.3 \%$ of the comments. Other approaches were discussing, researching, reflection and socialisation or hidden curriculum. Some participants wanted students to take a leading role in their learning and still some lecturers described teaching as subjective as evident in differences among themselves when selecting teaching approaches. Lecturers' use of various teaching approaches was consistent with students' use of various activities when learning.

Participants' preferred use of the lecture method, probably, was linked to a culture of lecturing, though student teachers and lecturers knew that the lecture method was not the best. The lecturers' role was giving information often in the form of notes, explaining, giving examples, posing questions and sometimes providing answers. Student teachers' role was listening, answering questions, and taking down notes. S3 believed that some lecturers always borrowed ideas from others, and sometimes used one source, and found lectures boring.

Take for example a lecture method. The lecturer goes in front of students and just gives information and thereafter poses some questions. Then he moves around checking how students are answering the questions. The lecture method seems appropriate with large groups of students. The students are passive listeners and the lecturer just moves around... Then in other instances (laughing) lecturers used the lecture method (continues to laugh). We were given notes, and our responsibility was to take down the notes. After writing the lecturer would explain one or two things and give us questions or an assignment, and pointed out what we were going to do in the coming lecture. It was basically the lecture method and guided discovery. (Interview with S3)

According to student S4, the common classroom discourse was transmission, and teachers' main focus was teaching content. To him teaching entailed giving notes, assignments and answers, discussing what the students found difficult and displaying solutions in Mathematics. In a typical Mathematics lesson during ASE student teacher S4 introduced new concepts, then gave tasks to pupils to practice, and checked answers. It seems the focus of teaching was content, and student teachers enjoyed showing their pupils that they knew the subject matter well.

I was only involved in teaching Mathematics at A-Level because students did not have a teacher. I was concentrating on teaching content... I wrote schemes of work, lesson plans and worked out solutions... I normally gave an assignment to the students. During the first 20 minutes I gave the students solutions to the assignment. They used these to mark their work. If there were any problems the students had experienced we discussed these. Some students displayed their solutions on the board. I then asked the students to write corrections. Then I introduced new concepts say for 15 minutes by explaining and lecturing. I then gave students a task to do and go round checking progress. Often I interjected to give explanations... (Interview with S4)

Lecturer L4 describes two contrasting beliefs of role of teacher; as transmitter of knowledge, and as facilitator with the responsibility of helping students to construct own knowledge. He liked being a facilitator and using student-centred, 
interactive and participatory methods. When employing these approaches the lecturer's role was initiating the discussion, making presentations, and debating all these strategies used prior knowledge.

Let me start by telling you what I hope I do not do. I hope in my lectures I do not stand there and pretend that I know everything and that my students are simply there to absorb what I say. I think my job is, what I try to do is to provoke my students into learning. Yes they might not know what to learn but then my job is to expose them to possibilities that they have, that they should explore. I think my job is to enable them to learn how to teach by leading them to sources of literature, by creating activities that might enable them to want to learn more. I think more importantly, I have always said this, that the critical student can only be produced by critical teaching. In my lessons I tend to emphasize critical thinking... In my lecture they come prepared to say something, not just out of textbooks but to think through, to reflect on whatever topic we are looking at. Often I tell them well in hand what we are going to do and they come prepared to participate, to criticize what others and I have said and also to give their views. At the end of the day I want my students to think that they understood a concept because of their effort. (Interview with L4)

Despite L4's complex view of teaching and learning the dominant classroom discourse in teacher education at the university studied was the transmission mode. Participants' perceptions of their own identities and motives for becoming teachers shaped 'what', 'where' and 'how' student teachers were learning.

The data gathered in this study suggests that students, when they say they learn to teach at university, mean, probably, that they were learning subject matter knowledge. However, it also emerged that, when, lecturers thought they were teaching educational theory, students reported they were learning subject matter content. Therefore, at one level there was agreement among participants that learning to teach happens at university, but at the next level, there was disagreement because students focused on subject matter knowledge and lecturers talked about educational theory.

Perhaps this can be traced to motives; most students originally wanted to be scientists and mathematicians, so perhaps students regard being a scientist as more important than being a science teacher. Consequently, it could be argued that, it is not really surprising therefore that students valued subject matter knowledge more highly because that brings them close to what they originally wanted to be. Lecturers, however, being already committed to a career in education, were consequently committed to teaching educational theory and seeing students learning that. Student teachers sometimes reported to be recognizing these tensions but seemed to be taking little action to acknowledge and work with them. Even lecturers didn't seem to be aware of this and they hardly mentioned how they were helping students develop an interest in learning educational theory other than hoping that interest would develop naturally with time. They did not talk about how learning, both subject matter knowledge and educational theory taught together, can produce more effective teachers than separating the two.

\section{Discussion}

Data came from one sample of lecturers and two samples of student teachers following two routes of teacher education but doing the same courses. The two groups of students were pre-service and in-service student teachers. The participants' background is discussed in three parts; biography, identity and motives. First, participants characterize the biography of student teachers using gender, age and work experience. This study noted gender imbalances in both samples of student teachers learning to teach mathematics and science subjects at University of Mashonaland (UoM). More males trained as mathematics and science teachers than females at UoM. Lynch \& Feeley (2009) report similar findings in Europe where gender inequalities still remain in subject preferences and performance e.g. mathematics, science and technology (MST) courses were predominantly male in profile.

From my findings, a majority of student teachers were in the age group 21-30 years, with pre-service students generally younger than in-service students. The differences were understandable considering the routes followed where pre-service students were coming straight from high school, and in-service students had some training and work experience.

As expected, data suggests that in-service (student) teachers had more work experience than pre-service (student) teachers did and minority of pre-service student teachers had been temporary teachers before joining UoM. In Zimbabwe, schools employ job seekers as unqualified teachers if they have a minimum of five O-Level passes. Other temporary teachers could be A-level school leavers and university graduates. The common perception of participants was that work experience shaped students' pre-conceived ideas of teaching as a profession (Bruinsma \& Canrinus, 2012; Andrews \& Hatch, 2002). However, potential pre-service students were selected based on A-Level grades and not work experience. In contrast, in-service students must have both A-Level grades and a minimum of two years post diploma qualification work experience. I suggest that for consistency and fairness to be seen to be applied to all students, potential pre-service students should be helped to gain work experience before enrolling to train as teachers. 
Second, a majority of participants identified themselves with their positions in the university and school systems. The positioning(s) commonly used were student, teacher, and lecturer; chairperson and coordinator; science educator and theorist. This does not seem unusual, but, further scrutiny of these identities suggest power relations because they show hierarchy of authority, where a lecturer (who knows) is regarded as more powerful than a student (who has much to learn). My discoveries were consistent with Gee's (2005) notion of 'institutional perspective' of identity, that is, to be a student teacher or lecturer is a position authorised by the administration of the university. Lecturers had power "in terms of holding a set of rights and responsibilities that goes with that position" (Gee, 2005, p. 102), and the same is true of student teachers. However, identities of student teacher and lecturer have implications for learning to teach; probably, the implicit power relations meant that the lecturers determined 'what', 'where', 'when', 'how', 'with whom', and 'why' students were learning. Student teachers also determine many of these things, thereby generating conflicts with their lecturers' expectations.

Third finding of participants' background was that student teachers had varied motives for joining teaching. From a majority of participants' comments it was largely a matter of chance than a deliberate decision to want to teach, and the other motives were 'important other', remuneration, work experience and vocation. In a research by Chivore (1986) secondary pupils and their parents regarded teaching as a last resort. UoM student teachers' motives were similar to findings in the literature; job conditions, influence from others, extrinsic, and intrinsic/altruistic motivation (Fokkens-Bruinsma \& Canrinus, 2011; Low et al., 2011; Bruinsma \& Jansen; 2010; Hobson \& Malderez, 2005; Chan, 2004; Andrews \& Hatch, 2002). 'Work experience' as a motive is consistent with Andrews \& Hatch's (2002) finding that people became teachers because of their experiences as learners, and what Bruinsma \& Canrinus (2012) refer to as 'perceptions of the task'.

Comments from student-teachers revealed that they were learning mostly subject matter knowledge in the university setting. It is possible that student-teachers saw some courses, such as subject matter knowledge, as more important than others, such as educational theory and when talking about what they were learning, they were quick to mention their subjects of specialism. My data suggests that student-teacher participants did not like learning education courses (e.g. interview with S1) because they did not consider educational theory as important as subject matter knowledge. Another possible reason to explain why student-teachers were more interested in subject matter knowledge than education courses could be that most student-teachers found learning educational theory to be boring and difficult. There is literature in favour of putting emphasis in teacher learning on subject matter knowledge (e.g. Fajet et al., 2005; Darling-Hammond, 2000a; Grossman, 1994) as well favouring learning educational theory (e.g. Darling-Hammond, 2000b; Monk. 1994) and literature arguing for equally both forms of teacher knowledge (Watson et al., 2008; Darling-Hammond, 2000b). Teacher educators and student-teachers need a common understanding of the objects of teacher education - 'what' and 'how' people learn to teach.

\section{Conclusion}

Although motives are important determinants of engagement, in the university studied, data suggests prospective student teachers did not get places based on their motivation to become a teacher. The current selection of student teachers, solely based on A-Level and O-Level grades (and work experience for in-service teachers), would need to be supplemented with interviews to establish the motives of potential candidates because these influence learning. While student teachers had motives for training as teachers similar to those found in literature, at times, these were in conflict with the objectives of the teacher education programme studied.

The university should work closely with government, associations and unions of teachers to make teaching attractive to high ability student-teacher candidates. Student cadetship schemes, where student teachers received sponsorship and in turn worked for the government on graduation, was a good idea to attract candidates into teaching in countries facing economic hardships. Working conditions for teachers also need to be revised to keep pace with change in the wide community. Teachers need to feel respected and go to work assured that they are going to earn enough to meet their basic day-to-day needs. They need to be confident that they can make decisions within their professional work without fear of victimization. Therefore policymakers must put in place legal frameworks to safeguard the safety of workers in general, and teachers in particular, so that candidates can view teaching as a profession where you can work without fear.

\section{References}

Andrews, P., \& Hatch, G. (2002) Initial motivations of serving teachers of secondary mathematics. Evaluation and Research in Education, 16(4), 185-201. http://dx.doi.org/10.1080/09500790208667018

Bastick, T. (2000) Why Teacher Trainees Choose the Teaching Profession: Comparing Trainees in Metropolitan and Developing Countries. International Review of Education, 46(3), 343-349. http://dx.doi.org/10.1023/A:1004090415953 
Bogdan, R. C., \& Biklen, S. K. (Ed.) (1992). Qualitative Research for education. Boston, Allyn and Bacon.

Bruinsma, M. F., \& Canrinus, E. T. (2012). The factors influencing teaching (FIT)-Choice Scale in a Dutch teacher education program. Asia-Pacific Journal of Teacher Education, 40, 249-269. http://dx.doi.org/10.1080/1359866X.2012.700043

Bruinsma, M., \& Jansen, E. P. W. A. (2010) Is the motivation to become a teacher related to pre-service teachers' intentions to remain in the profession? European Journal of Teacher Education, 33(2), 185-200. http://dx.doi.org/10.1080/02619760903512927

Chan, K. (2004). Teacher professional development: In-service teachers' motives, perceptions and concerns about teaching. Hong Kong Teachers' Centre Journal, 3, 56-71.

Chireshe, R., \& Shumba, A. (2011). Teaching as a profession in Zimbabwe: are teachers facing a motivation crisis? Journal of Social Sciences, 28(2), 113-118.

Chivore, B. R. S. (1988). A review of factors that determine the attractiveness of teaching profession in Zimbabwe. International Review of Education, 34(1), 59-77. http://dx.doi.org/10.1007/BF00601918

Chivore, B. R. S. (1986). Form IV pupils' perception of and attitudes towards the teaching profession in Zimbabwe. Comparative Education, 22(3), 233-253. http://dx.doi.org/10.1080/0305006860220305

Cochran, S. M., \& Zeichner, M. (2005). Studying teacher education: The report of the AERA panel on research and teacher education. Lawrence Erlbaum Associates, Inc.

Czubaj, C. A. (1996). Maintaining teacher motivation. Education, 116(3), 372-378.

Darling, H. L. (2000a). How Teacher Education Matters. Journal of Teacher Education, 51(3), 166-173. http://dx.doi.org/10.1177/0022487100051003002

Darling, H. L. (2000b). Teacher quality and student achievement: A review of state policy evidence. Educational Policy Analysis Archives, 8, http://epaa.asu.edu/epaa/v8n1/2000

Fajet, W., Bello, M., Leftwich, S. A., Mesler, J. L., \& Shaver, A. N. (2005). Pre-service teachers' perceptions inbeginning education classes. In Teaching and Teacher Education, 21, 717-727. http://dx.doi.org/10.1016/j.tate.2005.05.002

Fokkens, B. M., \& Carinus, E. (2011). Motivation to become a teacher in a Dutch university-based teacher training programme. Paper presented at the European Association for Research on Learning and Instruction (EARLI), International Conference, Exeter, UK.

Gee, J. P. (2005). An introduction to discourse analysis: Theory and method. New York: Routledge.

Gee, J. P. (2003). What video games have to teach about learning and literacy. New York: Palgrave Macmillan.

Gee, J. P. (2001). Identity as an analytical lens in for research in education. Review of Research in Education, 25, 99-125. Grossman, P., Valencia, S., Evans, K., Thompson, C., Martin, S., \& Place, N. (eds) (2000) Transitions into teaching: Learning to teach writing in teacher education and beyond. New York: Office of Educational Research and Improvement.

Guyton, E., \& Farokhi, E. (1987). Relationships among academic performance, basic skills, subject matter knowledge, and teaching skills of teacher education graduates. Journal of Teacher Education, 36(3), 160-189

Hobson, A. J., \& Malderez, A. (2005). Becoming a teacher: student teachers' motives and pre-conceptions, and early school-based experiences during Initial Teacher training (ITT) Research Report 673. London: Department of Education and Skills (DfES).

Low, E. L., Lim, S. K., Ch'ng, L., \& Goh, K. C. (2011). Pre-service teachers' reasons for choosing teaching as a career in Singapore. Asia Pacific Journal of Education, 31(2), 195-210. http://dx.doi.org/10.1080/02188791.2011.567441

Lynch, K., \& Feeley, M. (2009). Gender and education (and employment): gendered imperatives and their implications for women and men - lessons from research for policy makers. www.nesse.fr

Kyracou, C., \& Coulthard, M. (2000). Undergraduates' views of teaching as a career choice. Journal of Education for Teaching, 26, 117-126. http://dx.doi.org/10.1080/02607470050127036

Meijer, P. C., Verloop, N., \& Beijaard, D. (1999). Exploring language teachers practical knowledge about teaching reading comprehension. Teaching and teacher education, 15, 59-84. http://dx.doi.org/10.1016/S0742-051X(98)00045-6

Minor, L. C., Onwuegbuzie, A. J., \& Witcher, A. E. (2000). Pre-service teachers' perceptions of characteristics of 
effective teachers: A multi-stage mixed methods analysis. Paper presented at the Annual Meeting of the Mid-South Educational Research Association, Lexington, KY.

Monk, D. H. (1994). Subject Matter preparation of secondary mathematics and science teachers and student achievement. In Economics of Education Review, 13(2), 125-145. http://dx.doi.org/10.1016/0272-7757(94)90003-5

Muhwezi, D. K. (2003). Gender sensitive educational policy and practice: a Uganda case study. Paper commissioned for the EFA Global Monitoring Report 2003/4, the Leap to Equality. UNESCO

Mulkeen, A., Chapman, D. W., DeJaeghere, J. G., \& Leu, E. (2007). Recruiting, retaining and re-training secondary school teachers and principals in Sub-Saharan Africa. World Bank Working Paper No. 99: Human Development Series. Washington, DC.: World Bank. http://dx.doi.org/10.1596/978-0-8213-7066-7

Postlethwaite, K., \& Haggarty, L. (2010). Student-teachers' thinking about learning to teach: a study of student-teachers of mathematics and science at the end of their initial training. Research papers in Education, 1-22, iFirst article.

Reid, I., \& Caudwell, J. (1997). Why did secondary PGCDE students choose teaching as a career? Research in Education, 58, 46-58.

Richardson, P. W., \& Watt, H. M. G. (2005). I've decided to become a teacher: Influences on career change. Teaching and Teacher Education, 21, 475-489. http://dx.doi.org/10.1016/j.tate.2005.03.007

Rikard, G. L. (1999). Promoting teacher commitment in pre-service teachers. Journal of Physical Education, Research and Dance, 20(91), 53-56. http://dx.doi.org/10.1080/07303084.1999.10605969

Roth, W. M., \& Tobin, K. (2001). Learning to teach science as practice. Teaching and Teacher Education, 17, 741-762. http://dx.doi.org/10.1016/S0742-051X(01)00027-0

Stake, R. E., Ed. (1995). The art of case study research. Thousand Oaks, CA, SAGE.

Thomson, M. M., Turnber, J. E., \& Nietfeld, J. L. (2012) A typological approach to investigate the teaching career decision: Motivations and beliefs about teaching of prospective teacher candidates. Teaching and Teacher Education, 28, 324-335. http://dx.doi.org/10.1016/j.tate.2011.10.007

Trent, J. (2011). The professional development of teacher identities in Hong Kong: can a short-term course make a difference? Professional Development in Education, 33(4), 613-632. http://dx.doi.org/10.1080/19415257.2011.576262

Trotman, J., \& Kerr, T. (2001). Making the personal professional: Pre-service teacher education and personal histories. Teachers and Teaching: Theory and Practice, 7(2), 157-171. http://dx.doi.org/10.1080/13540600120054955

Verloop, N., van Driel, J. H., \& Meijer, P. C. (2001). Teacher knowledge and Knowledge base of teaching. International Journal of Educational Research, 35(5), 441-461. http://dx.doi.org/10.1016/S0883-0355(02)00003-4

Watson, L., Hay, I., Hellyer, L., Stckey, D., \& Woolnough, J. (2008). Beyond the practicum: integrating content, pedagogy and practice in teacher education. Peer Refereed Conference Paper delivered to the Australian Association for Research in Education (AARE) National Conference, 30 November - 4 December 2008, Brisbane

Whitehead, J., \& Postlethwaite, K. (2000). Recruitment, access and retention: some issues for secondary initial teacher education in the current social context. Research in Education, 64, 44-55. http://dx.doi.org/10.7227/RIE.64.5

Witcher, A., Onwuegbuzie, A. J., \& Minor, L. C. (2001). Characteristics of effective teachers: Perceptions of pre-service teachers. Research in the Schools, 8, 45-57.

Yong, B. C. (1995). Teachers' motives for entering into a teaching career in Brunei Darussalam. Teaching and Teacher Education, 11(3), 275-280. http://dx.doi.org/10.1016/0742-051X(94)00023-Y

Younger, M., Brindley, S., Peddler, D., \& Hagger, H. (2004). Starting points: student teachers' reasons for becoming teachers and their preconceptions of what this will mean. European Journal of Teacher Education, 27(3), 245-264. http://dx.doi.org/10.1080/0261976042000290787

This work is licensed under a Creative Commons Attribution 3.0 License. 